\title{
PENANGGULANGAN KEMISKINAN MELALUI PEREKONOMIAN PARTISIPATIF
}

\author{
I Wayan Sutrisna \\ Fakultas Ilmu Sosial dan Ilmu Politik, Universitas Mahendradatta - Denpasar \\ e-mail : sutrisna76@yahoo.co.id
}

\begin{abstract}
Abstrak - Problematika kemiskinan hingga saat ini masih merupakan ancaman bagi setiap pemerintahan yang ada di dunia ini. Tingkat kemiskinan akan dapat dijadikan salah satu indikator dalam menilai keberhasilan sebuah rezim pemerintahan yang berkuasa. Negara-negara maju sekalipun yang memiliki sumber daya yang berlimpah dan teknologi yang mumpuni masih menyimpan kantong-kantong kemiskinan di beberapa sudut wilayahnya. Komite Penanggulangan Kemiskinan Republik Indonesia memberikan pandangan bahwa kemiskinan merupakan kondisi dimana seseorang atau sekelompok orang, laki-laki dan perempuan, tidak terpenuhinya hak-hak dasarnya secara layak untuk memenuhi dan mengembangkan kehidupan yang bermartabat.

Pelibatan masyarakat secara maksimal dalam sektor perekonomian bertujuan memberikan akses seluas-luasnya kepada masyarakat untuk berkontribusi dan menikmati hasil dari pertumbuhan ekonomi yang dihasilkan. Sistem perekonomian yang melibatkan masyarakat banyak dalam proses perekonomian akan mampu mengarahkan perekonomian suatu wilayah menuju pertumbuhan yang berkualitas. Perekonomian yang partisipatif merupakan salah satu solusi dalam penanganan komleksitas masalah kemiskinan. Masyarakat yang berdaya dalam perekonomian pastilah dapat meningkatkan sumber pendapatannya sehingga berujung pada peningkatan kesejahteraan secara umum. Pemberdayaan masyarakat dalam perekonomian sangat diperlukan dalam proses pembangunan khusunya dalam bidang ekonomi.

Ekonomi kerakyatan yang merupakan sistem perekonomian yang paling sesuai dengan budaya Indonesia seperti tertuang dalam konstitusi negara kita harus benar-benar diterapkan dalam mencapai tujuan nasional. UMKM, Koperasi dan lembaga-lembaga perekonomian milik masyarakat luas harus terus dikembangkan agar masyarakat lebih berdaya dalam sektor ekonomi. Strategi penanggulangan kemiskinan dengan memberikan kesempatan kepada masyarakat untuk ikut menikmati keberhasilan sektor ekonomi akan mampu menekan jumlah kemiskinan secara luas. Perekonomian partisipatif yang berhasil diterapkan dalam suatu wilayah diyakini akan mampu mengangkat perekonomian kearah pertumbuhan ekonomi yang berkualitas.
\end{abstract}

Kata kunci: partisipasi, perekonomian dan kemiskinan

\begin{abstract}
The problem of poverty is still a threat to every government in the world. The poverty level will be used as an indicator in assessing the success of a ruling government regime. Even developed country that has abundant resources and capable technology was still keeping pockets of poverty in several corners of the region. The Poverty Reduction Committee of the Republic of Indonesia gives the view that poverty is a condition where a person or group of people, men and women, cannot fulfill their basic rights properly to fulfill and develop a dignified life.

Maximum involvement of the community in the economic sector aims to provide the widest possible access to the community to contribute and enjoy the results of the economic growth generated. The economic system that involves many people in the economic process will be able to direct the economy of a region towards quality growth. A participatory economy is one solution in handling the complexity of poverty. A powerless society in the economy must be able to increase its source of income so that it ends in increasing welfare in general. Community empowerment in the economy is very much needed in the development process especially in the economic field.

The people's economy which is an economics system that is most in line with Indone-
\end{abstract}


sian culture as stated in our country's constitution must be truly implemented in achieving national goals. MSMEs, Cooperatives and economic institutions belonging to the wider community must continue to be developed so that the community is more empowered in the economic sector. The poverty reduction strategy by providing opportunities for the community to enjoy the success of the economic sector will be able to reduce the amount of poverty widely. The participatory economy that has been successfully implemented in a region is believed to be able to lift the economy towards quality economic growth.

Keywords: participation, economic, poverty

\section{A. Pengantar}

Tujuan dibentuknya Negara Kesatuan Republik Indonesia adalah seperti yang termuat dalam pembukaaan Undang-Undang dasar 1945 alinia IV yaitu " melindungi segenap bangsa Indonesia dan seluruh tumpah darah Indonesia dan untuk memajukan kesejahteraan umum, mencerdaskan kehidupan bangsa, dan ikut melaksanakan ketertiban dunia yang berdasarkan kemerdekaan, perdamaian abadi dan keadilan sosial". Untuk mencapai tujuan tersebut maka pemerintah sejak negara ini berdiri telah melaksanakan proses pembangunan menuju tercapainya tujuan nasional seperti yang telah dirumuskan. Pembangunan Nasional merupakan usaha untuk meningkatkan seluruh aspek kehidupan masyarakat, bangsa dan negara yang sekaligus merupakan proses pengembangan dan pemberdayaan seluruh komponen dalam kehidupan bernegara guna mewujudkan tujuan nasional. Proses Pembangunan di Indonesia memiliki tujuan yang multidimensional yang salah satunya adalah mewujudkan masyarakat Indonesia yang demokratis, karena dengan keadaan yang lebih demokratis memungkinkan masyarakat lebih terbuka untuk berpartisipasi dalam pembangunan di segala bidang. Perkembangan pembangunan yang semakin cepat dan sangat kompleks menuntut seluruh komponen yang terlibat dalam proses pembangunan dan demokrasi mampu mewujudkan apa yang menjadi tujuan dari pembangunan NKRI.

Hakikat dari Pembangunan nasional adalah pembanguan yang dilaksanakan secara merata untuk seluruh masyarakat dan wilayah Indonesia. Pembangunan dilaksanakan bersama oleh masyarakat dan pemerintah. Masyarakat adalah pela$\mathrm{ku}$ utama pembangunan dan pemerintah berkewajiban mengarahkan, membimbing serta menciptakan suasana yang menunjang kelancaran proses pembangunan. Kegiatan masyarakat dan pemerintah harus saling mendukung, saling mengisi dan saling melengkapi dalam satu kesatuan gerak menuju tercapainya satu tujuan yakni tujuan pembangunan nasional. Masalah yang masih sangat krusial dalam proses pembangunan di negeri ini yakni belum meratanya hasil pembangunan bagi seluruh wilayah Indonesia, terlalu tinggi kesenjangan antara pembangunan di Indonesia bagian barat khusunya Jawa dengan daerah Indonesia Tengah dan Timur. Hasil-hasil pembangunan belum merata dinikmati oleh seluruh wilayah di Tanah Air. Bahkan ada daerah yang sumbangan pajaknya sangat tinggi bagi negeri ini karena memiliki hasil tambang yang besar malahan daerahnya sebagaian besar merupakan daerah tertinggal.

Salah satu indikator dalam mengukur keberhasilan proses pembangunan di suatu negara/daerah adalah rendahnya tingkat kemiskinan di wilayah tersebut. Kemiskinan hingga saat ini masih merupakan "momok" serta kegagalan bagi setiap pemerintahan yang ada di dunia ini. Oleh karena itu setiap pemerintahan sangat berusaha keras untuk meninggalkan kemiskinan dari wilayahnya. Karena masalah kemiskinan ini sangat kompleks dan perlu penanganan yang komprehensif dan periodik, maka perlu diformulasikan strategi penanggulangan kemiskinan yang berbasis partisispasi masyarakat. Banyak sekali daerah di Indonesia yang terlihat maju dari tampilan luarnya, namun menyimpan cukup banyak masyarakat miskin yang masih termarjinalkan dalam proses pembangunan yang dilaksanakan. Seperti halnya di Bali yang merupakan daerah tujuan wisata dunia, masih tersimpan penduduk miskin, meski jumlahnya masih di bawah rata-rata nasional. 
Tabel. 1

Penduduk Miskin di Bali tahun 2010 hingga 2018

\begin{tabular}{|l|r|r|r|r|r|r|r|r|r|}
\hline \multirow{2}{*}{$\begin{array}{c}\text { Kabupaten/ } \\
\text { Kota }\end{array}$} & \multicolumn{10}{|c|}{ Jumlah Penduduk Miskin (Ribu Jiwa) } \\
\cline { 2 - 12 } & $\mathbf{2 0 1 9}$ & $\mathbf{2 0 1 1}$ & $\mathbf{2 0 1 2}$ & $\mathbf{2 0 1 3}$ & $\mathbf{2 0 1 4}$ & $\mathbf{2 0 1 5}$ & $\mathbf{2 0 1 6}$ & $\mathbf{2 0 1 7}$ & $\mathbf{2 0 1 8}$ \\
\hline Jembrana & 21.3 & 17.6 & 15.3 & 14.92 & 15.8 & 15.83 & 14.52 & 14.78 & 14.35 \\
\hline Tabanan & 29,2 & 24.2 & 21 & 22.49 & 24.4 & 24.05 & 21.9 & 21.66 & 19.77 \\
\hline Badung & 17.7 & 14.6 & 12.51 & 14.55 & 15.4 & 14.4 & 12.91 & 13.16 & 12.97 \\
\hline Gianyar & 31.5 & 26 & 22.63 & 20.8 & 22.5 & 22.89 & 22.13 & 22.42 & 21.26 \\
\hline Klungkung & 12.9 & 10.7 & 9.3 & 12.21 & 12.3 & 12.11 & 11.21 & 11.15 & 10.43 \\
\hline Bangli & 13.8 & 11.4 & 9.9 & 12 & 13 & 12.74 & 11.66 & 11.76 & 11.05 \\
\hline Karangasem & 31.6 & 26.1 & 22.68 & 27.85 & 29.7 & 30.33 & 27.12 & 27.02 & 26.02 \\
\hline Buleleng & 45.9 & 37.9 & 32.96 & 40.32 & 43.7 & 43.43 & 37.55 & 37.48 & 35.2 \\
\hline Denpasar & 17.5 & 14.5 & 12.66 & 17.63 & 19.2 & 20.94 & 19.17 & 20.7 & 20.72 \\
\hline Provinsi Bali & 221.6 & 183.1 & 158.95 & 182.77 & 196 & 196.71 & 178.18 & 180.13 & 171.76 \\
\hline
\end{tabular}

Sumber: BPS Provinsi Bali

Tabel. 1 di atas menunjukkan bahwa jumlah masyarakat miskin di Bali secara keseluruhan mengalami fluktusasi dari tahun ke tahun. Dari sebaran daerah kabupaten/ kota juga terjadi perbedaan yang cukup besar antar wilayah yang ada di Provinsi Bali. Masyarakat miskin di Bali lebih banyak ada didaerah-daerah bali utara seperti Buleleng dan Karangasem. Sementara daerah di bagian selatan pulau Bali tetap juga memiliki masyarakat miskin namun jumlahnya relatif sedikit. Daerah selatan seperti Badung dan Denpasar merupakan kawasan Pariwisata sebagai sumber utama Pendapatan daerahnya sehingga dapat digunakan oleh Pemda untuk melaksanakan program penanggulangan kemiskinan.

\section{B. Problematika Kemiskinan di Indo- nesia}

Kemiskinan sebagai masalah klasik dalam setiap pemerintahan tidak dapat ditanggulangi hanya oleh pemerintah saja, namun semua komponen yang ada dalam sebuah negara/daerah harus terlibat dalam penanggulangan kimiskinan ini. Dalam buku Strategi Nasional Penanggulangan Kemiskinan yang disusun oleh Komite Penanggulangan Kemiskinan Republik Indonesia memberikan pandangan bahwa kemiskinan merupakan kondisi dimana seseorang atau sekelompok orang, laki-la- ki dan perempuan, tidak terpenuhinya hak-hak dasarnya secara layak untuk memenuhi dan mengembangkan kehidupan yang bermartabat. Kemiskinan tidak lagi dipahami hanya sebatas ketidakmampuan ekonomi, tetapi juga kegagalan pemenuhan hak-hak dasar dan perbedaan perlakuan bagi seseorang atau sekelompok orang, laki-laki dan perempuan, dalam menjalani kehidupan secara bermartabat.

Hak-hak dasar terdiri dari hak-hak yang dipahami masyarakat miskin sebagai hak mereka untuk dapat menikmati kehidupan yang bermartabat dan hak yang diakui dalam peraturan perundang-undangan. Hak-hak dasar yang diakui secara umum antara lain terpenuhinya pangan, kesehatan, pendidikan, pekerjaan, perumahan, air bersih, pertanahan, sumber daya alam dan lingkungan hidup, rasa aman dari perlakuan tindak kekerasan, dan hak untuk berpartisipasi dalam kehidupan sosial, ekonomi dan politik, baik bagi perempuan maupun laki-laki. Hak-hak dasar tidak berdiri sendiri tetapi saling mempengaruhi satu sama lainnya sehingga tidak terpenuhinya satu hak dapat mempengaruhi pemenuhan hak lainnya.

Kemiskinan juga dipandang sebagai proses perampasan atas daya rakyat miskin. Konsep ini memberikan pengakuan bahwa orang miskin terpaksa menjalani kemiskinan dan sering kali mengalami 
pelanggaran hak yang dapat merendahkan martabatnya sebagai manusia. Oleh karena itu, konsep ini memberikan penegasan terhadap kewajiban negara untuk menghormati, melindungi dan memenuhi hakhak dasar masyarakat miskin.

Menurut Todaro (2004) kemiskinan adalah rendahnya pendapatan perkapita dan lebarnya kesenjangan dalam distribusi pendapatan. Para ahli ekonomi pembangunan mulai mengukur luasnya atau kadar parahnya tingkat kemiskinan di dalam suatu negara dan kemiskinan relatif antar negara dengan cara menentukan atau menciptakan suatu batasan yang lazim disebut sebagai garis kemiskinan (poverty line). Konsep yang digunakan adalah konsep kemiskinan absolut (absolute poverty) yaitu konsep untuk menentukan tingkat pendapatan minimum yang cukup untuk memenuhi kebutuhan-kebutuhan fisik minimum setiap orang berupa kecukupan makanan, pakaian serta perumahan sehingga dapat menjamin kelangsungan hidupnya.

Kemiskinan sebagai proses sistemik yang tereduksi dari berbagai faktor. Kemiskinan lebih merupakan sebuah keadaan yang dipengaruhi secara sistematik yang di dalamnya dipengaruhi oleh banyak aspek. Kemiskinan dibentuk melalui kondisi suatu negara dari waktu ke waktu. Dengan demikian kemiskinan tidak terlepas dari bagaimana program yang dicanangkan, kebijakan alokasi sumber daya dan termasuk bagaimana kondisi yang terealisasi melalui perjalanan sejarah bangsa, kebijakan pembangunan, kemampuan sumber daya baik natural resources, teknologi, sumber daya manusia, selain itu juga manajemen dan distribusi sumber daya tersebut. Dengan demikian masalah kemiskinan adalah merupakan hal yang cukup kompleks. Salah satu generalisasi (anggapan sederhana) mengenai penduduk miskin adalah bahwa mereka pada umumnya bertempat tinggal di daerah-daerah pedesaan, yang mata pencahariannya adalah sebagai petani dan kegiatannya berkaitan erat dengan sektor ekonomi tradisional.

Lembaga penelitian SMERU mengemukakan bahwa pengertian kemiskinan harus mencakup berbagai dimensi sebagai berikut.

1) Ketidakmampuan memenuhi kebutuhan konsumsi dasar (sandang, pangan, papan).

2) Tidak adanya akses terhadap kebutuhan hidup dasar lainnya (kesehatan, pendidikan, sanitasi, air bersih, dan transportasi).

3) Tidak adanya jaminan masa depan (karena tiadanya investasi untuk pendidikan dan keluarga).

4) Kerentanan terhadap goncangan yang bersifat individual maupun massal.

5) Rendahnya kualitas sumber daya manusia dan keterbatasan sumber daya alam.

6) Tidak dilibatkan dalam kegiatan sosial masyarakat.

7) Tidak adanya akses terhadap lapangan kerja dan mata pencaharian yang berkesinambungan.

8) Ketidakmampuan untuk berusaha karena cacat fisik maupun mental.

9) Ketidakmampuan dan ketidakberuntungan sosial (anak-anak terlantar, wanita korban kekerasan rumah tangga, janda miskin, kelompok marjinal dan terpencil).

Kemiskinan merupakan kegagalan pemerintah dalam mengalokasikan sumber-sumber yang ada sehingga sebagian masyarakat yang "kurang beruntung" tidak dapat menikmati hasil dari apa yang telah dilakukan oleh pemerintah meskipun hasil itu hak seluruh masyarakat. Kemiskinan yang terjadi di suatu negara/wilayah disebabkan oleh banyak faktor antara lain :

1) Kegagalan kepemilikan terutama lahan dan modal.

2) Terbatasnya ketersediaan bahan kebutuhan dasar, sarana dan prasarana.

3) Kebijakan pembangunan yang bias perkotaan dan bias sektor.

4) Adanya perbedaan kesempatan diantara anggota masyarakat dan sistem yang kurang mendukung.

5) Adanya perbedaan sumber daya manusia dan perbedaan antar sektor ekonomi (ekonomi tradisional versus ekonomi modern)

6) Rendahnya produktivitas dan tingkat pembentukan modal dalam masyarakat.

7) Budaya hidup yang dikaitkan dengan kemampuan seseorang mengelola sumber daya alam dan lingkungannya.

8) Tidak adanya tata pemerintahan yang bersih dan baik (good governance).

9) Pengelolaan sumber daya alam yang 
berlebihan dan tidak berwawasan lingkungan.

\section{Menguatkan Partisipasi Masyarakat dalam Perekonomian}

Partisipasi masyarakat dalam proses pembangunan merupakan kunci utama suksesnya pelaksanaaan pembangunan tersebut. Partisipasi masyarakat dalam pembangunan khususnya pembanguanan ekonomi akan menempatkan masyarakat sebagai motor penggerak atau sebagai subyek bukan hanya sebagai obyek saja. Dengan Partisispasi ini membuat masyarakat akan merasa memiliki serta ikut bertanggungjawab terhadap setiap proses dan hasil-hasil pembangunan. Partisipasi masyarakat akan mengarah kepada pemberdayaan masyarakat karena melalui partisipasi dalam seluruh proses, masyarakat akan semakin berdaya dan mampu mengendalikan proses tersebut kearah pencapaian kesejahteraan masyarakat itu sendiri.

Penduduk Indonesia yang saat ini mencapai lebih dari seperempat milyar orang merupakan potensi yang luar biasa bagi penopang proses pembangunan ekonomi di negeri ini. Sumber daya manusia yang dimiliki ini apabila diarahkan dengan optimal akan mampu menjadi kekuatan utama pendukung pembangunan nasional. Namun keberadaan penduduk yang banyak ini kadang juga merupakan hambatan yang sangat mengganggu proses pembangunan. Penduduk yang acuh tak acuh dan tidak peduli dengan kehidupan berbangsa dan bernegara akan menjadi hambatan dalam pembangunan ini. Mereka tidak akan ikut melibatkan diri atau berpartisipasi dalam proses pembangunan sehingga apa yang menjadi tujuan pembangunan nasional tidak akan tercapai.

Masyarakat yang partisipatif dalam proses pembangunan mengandung arti bahwa masyarakat berinisiatif memulai proses kegiatan untuk perubahan kearah yang lebih baik. Pertisipasi masyarakat hanya bisa terjadi apabila warganya ikut aktif. Jumlah penduduk yang banyak serta diimbangi dengan partisipasi yang tinggi membuat penduduk menjadi kekuatan besar dalam segala kegiatan berbangsa dan bernegara. Hal ini akan menjadi modal dan kekuatan untuk mensukseskan pembangunan nasional.
Masyarakat yang partisipatif sangat dibutuhkan dalam proses pemerintahan dan pembangunan. United Nation Develepment Program (UNDP) bahkan telah memasukkan partisipasi masyarakat dalam salah satu indikator atau karakteristik pemerintahan yang baik (Good Governance). Hal ini mengandung arti bahwa semakin tinggi tingkat partisipasi masyarakat dalam proses pemerintahan dan pembangunan menunjukkan bahwa pemerintahan yang berkuasa telah melaksankan proses pemerintahan yang baik.

Partisipasi Masyarakat adalah suatu proses dimana masyarakat, terutama mereka yang miskin sumber daya, kaum perempuan dan kelompok yang terabaikan lainnya, didukung agar mampu meningkatkan kesejahteraannya secara mandiri. Ini mengandung arti bahwa masyarakat diberikan peluang serta dorongan untuk memperbaiki kesejahteraanya secara aktif tidak hanya mengandalkan usaha dari pemerintah saja. Masyarakat yang aktif dan berdaya akan mampu meningkatkan kesejahteraanya sendiri dan pemerintah hanya memfasilitasi saja.

Dalam sektor perekonomian perlu dibuatkan regulasi yang memperkuat peran serta masyarakat umum dalam aktivitas perekonomian. Sektor ekonomi yang melibatkan rakyat kecil harus tetap dijaga dari rambahan pengusaha-pengusaha besar. Pasar-pasar tradisional dan Usaha Mikro Kecil dan Menengah (UMKM) diberikan ruang untuk berkembang serta dikawal dalam bersaing dengan perusahan besar. Merambahnya toko-toko berjaringan yang dimiliki oleh pengusaha besar saat ini telah menjadi ancaman yang sangat serius bagi eksistensi warung-warung kecil milik masyarakat lokal. Apabila hal ini tidak disikapi dengan baik, maka keberadaan warung-warung kecil yang dimiliki oleh masyarakat lokal akan susah berkembang. Mewujudkan sistem perekonomian yang melibatkan masyarakat banyak dalam proses perekonomian akan mampu mengarahkan perekonomian suatu daerah menuju pertumbuhan yang berkualitas. Perekonomian yang partisipatif merupakan salah satu solusi dalam penanganan komleksitas masalah kemiskinan. Masyarakat yang berdaya dalam perekonomian akan mampu meningkatkan sumber pendapatannya sehingga berujung pada 
peningkatan kesejahteraan secara umum. Pemberdayaan masyarakat dalam perekonomian sangat diperlukan dalam proses pembangunan khusunya dalam bidang ekonomi.

\section{Mewujudkan Ekonomi Kerakyatan Menuju Indonesia Sejahtera}

Partisipasi masyarakat dalam perekonomian merupakan syarat mutlak untuk mewujudkan masyarakat yang berdaya dalam bidang ekonomi. Untuk mewujudkan partisipasi masyarakat maka disusun suatu konsep sistem perekonomian yang melibatkan seluruh masyarakat yakni sistem ekonomi kerakyatan. Ekonomi kerakyatan adalah sistem ekonomi yang berbasis pada kekuatan ekonomi rakyat. Ekonomi rakyat adalah kegiatan ekonomi atau usaha yang dilakukan oleh rakyat kebanyakan yang secara swadaya mengelola sumber daya ekonomi apa saja yang dapat diusahakan dan dikuasainya, dan selanjutnya disebut sebagai Usaha Kecil dan Menengah (UKM) terutama meliputi sektor pertanian, peternakan, kerajinan, makanan, dan sebagainya. Kegiatan ekonomi ini terutama ditujukan untuk memenuhi kebutuhan dasar dan keluarganya tanpa harus mengorbankan kepentingan masyarakat lainnya.

Menurut Prof. Dr. Mubyarto, Sistem ekonomi kerakyatan adalah sistem ekonomi yang berasas kekeluargaan, berkedaulatan rakyat, dan menunjukkan pemihakan sungguh-sungguh pada ekonomi rakyat. Dalam praktiknya, ekonomi kerakyatan dapat dijelaskan juga sebagai ekonomi jejaring (network) yang menghubungkan sentra-sentra inovasi, produksi, dan kemandirian usaha masyarakat ke dalam suatu jaringan berbasis teknologi informasi, untuk terbentuknya jejaring pasar domestik di antara sentra dan pelaku usaha masyarakat. Alfred Masrshall menyatakan bahwa Ekonomi Rakyat adalah kancah kegiatan ekonomi orang kecil yang karena merupakan kegiatan keluarga, tidak merupakan usaha formal berbadan hukum, tidak secara resmi diakui sebagai sektor ekonomi yang berperanan penting dalam perekonomian nasional.

Penerapan ekonomi kerakyatan di Indonesia tertuang dalam Konstitusi negara Indonesia yaitu Undang-Undang Dasar Negara Republik Indonesia Tahun 1945.
Ekonomi kerakyatan merupakan sistem ekonomi yang seharusnya dianut secara murni oleh Indonesia,sebab dalam Konstitusi negara telah diamanatkan dalam pasal 33 UUD 1945 yang berbunyi :

1) Perekonomian disusun sebagai usaha bersama berdasar atas asas kekeluargaan.

2) Cabang-cabang produksi yang penting bagi negara dan yang menguasai hajat hidup orang banyak dikuasai oleh Negara.

3) Bumi dan air dan kekayaan alam yang terkandung di dalamnya dikuasai oleh negara dan dipergunakan untuk sebesar-besar kemakmuran rakyat.

4) Perekonomian nasional diselenggarakan berdasar atas demokrasi ekonomi dengan prinsip kebersamaan, efisiensi berkeadilan, berkelanjutan, berwawasan lingkungan, kemandirian, serta dengan menjaga keseimbangan kemajuan dan kesatuan ekonomi nasional.

Pasal 33 dalam UUD 1945 ini menyatakan dengan jelas bahwa, ekonomi dilakukan seluas-luasnya untuk kepentingan rakyat. Justru yang terjadi adalah perekonomian yang dijalankan hanya menguntungkan beberapa pihak saja. Perekonomian nasional dikuasai oleh segelintar masyarakat Indonesia. Pertumbuhan ekonomi yang dicatatkan oleh BPS ternyata dinikmati hanya oleh sebagaian kecil masyarakat Indonesia khususnya para konglemerat. Sistem ekonomi kita masih belum berpihak kepada kepentingan ekonomi masyarakat kecil. Usaha pemerintah menuju penerapan ekonomi kerakyatan sudah berangsur mengarah ke hal yang positif. Pemerintah mulai memberikan prioritas kepada sektor-sektor yang berhubungan dengan ekonomi kerakyatan. Ada sejumlah sektor yang menjadi fokus pemerintah dalam pelaksanaan ekonomi kerakyatan, yakni:

\section{Koperasi}

Dalam UUD 1945 yakni pasal 33 ayat 1 dijelaskan bahwa Perekonomian disusun sebagai usaha bersama berdasarkan atas asas kekeluargaan. Hal inilah menjadi dasar pembentukan koperasi di Indonesia. Koperasi adalah badan hukum yang didirikan oleh orang perseorangan atau badan hukum Koperasi, dengan pe- 
misahan kekayaan para anggotanya sebagai modal untuk menjalankan usaha yang memenuhi aspirasi dan kebutuhan bersama di bidang ekonomi, sosial, dan budaya sesuai dengan nilai dan prinsip koperasi. Koperasi merupakan "Soko Guru" perekonomian Indonesia. Koperasi merupakan salah satu contoh ekonomi kerakyatan yang ada di Indonesia. Pada masa orde baru, keberadaan koperasi sangat membantu masyarakat dalam melakukan aktivitas perekonomian di desa. Saat itu hampir di setiap desa berdiri Koperasi Unit Desa (KUD). Menjelang pergantian rezim kekuasaan orde baru, banyak KUD mengalami kegagalan dan menghentikan usahanya atau bangkrut. Namun saat ini eksistensi koperasi mulai menggeliat kembali. Usaha-usaha koperasi yang ada saat ini lebih banyak berupa koperasi simpan pinjam yang dipergunakan oleh para anggota untuk menunjang kegiatan ekonomi mereka menuju ke arah kemakmuran.

\section{Usaha Mikro Kecil dan Menengah (UMKM)}

Usaha Mikro Kecil dan Menengah (UMKM) juga merupakan contoh penerapan ekonomi kerakyatan di Indonesia. Pemerintah saat ini terus berusaha membina dan merangsang tumbuh kembangnya UMKM di Indonesia. Salah satu rangsangan yang diberikan berupa pemberian kemudahan memasuki pasar Internasional. Hal ini membuat UMKM terutama yang bergerak dalam bidang kerajinan tangan yang merupakan komoditas unggulan untuk pasar Internasional saat ini semakin menggeliat. Produk kerajinan Indonesia sangat diminati oleh pasar Internasional khususnya pasar Eropa. UMKM sangat tergantung pada kreatifitas masyarakat dalam menghasilkan produk kerajinan. Selain produk berupa kerajinan atau karya seni produk UMKM unggulan saat ini yang diminati oleh pasar dalam negeri adalah usaha pengolahan makanan. Dengan dukungan pemasaran melalui sistem on-line produk usaha ini semakin berkembang dan sangat menjanjikan. Dengan semakin majunya UMKM yang dikelola oleh masyarakat sebagai pelaksanaan ekonomi kerakyatan akan dapat membangkitkan perekonomian dengan pertumbuhan ekonomi yang berkualitas. Data UMKM di Bali seperti yang dimuat oleh Tribun Bali.com pada tanggal 13 Januari 2019, menunjukkan per Maret 2018 jumlah UMKM di Bali berada di angka 312.967. Jumlah tersebut tersebar di masing-masing kabupaten/kota yang ada di Bali yang terbagi ke dalam empat kategori, berupa perdagangan, industri pertanian, industri non-pertanian dan aneka jasa. Kabupaten Bangli memiliki jumlah UMKM terbanyak yakni 43.948, sementara yang paling sedikit adalah Kabupaten Klungkung yang hanya di angka 9.712.

\section{Pasar Tradisional}

Pasar tradisinal merupakan aktivitas ekonomi bagi pelaku ekonomi kerakyatan. Pasar tradisional selalu menjadi tempat transaksi antara penjual dan pembeli dalam memperoleh suatu barang. Kelebihan pasar tradisional dengan pasar modern adalah terdapat proses tawar menawar sehingga menimbulkan komunikasi dua arah antara penjual dan pembeli. Meskipun saat ini ada banyak pusat perbelanjaan dan pasar swalayan modern, namun pasar tradisional sebagai aktivitas ekonomi kerakyatan tidak akan ditinggalkan oleh masyarakat, karena dalam pasar tradisional konsumen dapat memilih sendiri barang dan harga yang diinginkan.

Kualitas dan kuantitas ekonomi kerakyatan di Indonesia akan sangat menentukan keberhasilan pimpinan pemerintahan dalam menjalankan amanat Konstitusi negara. Perekonomian yang maju tapi dikuasai oleh konglemerasi bukan merupakan keberhasilan dalam sistem ekonomi di Indonesia. Ekonomi dengan pemberdayaan masyarakat secara luas adalah cita-cita yang ingin dicapai oleh seluruh rakyat Indonesia.

Dampak ekonomi kerakyatan bagi masyarakat di Indonesia sangat besar. Hal ini dikarenakan Ekonomi kerakyatan dikembangkan berdasarkan pengetahuan dan keterampilan masyarakat lokal dalam mengelola lingkungan dan tanah mereka secara turun temurun. Dalam Sistem ekonomi kerakyatan, masyarakat harus aktif dalam kegiatan ekonomi, sedangkan pemerintah menciptakan iklim yang sehat bagi pertumbuhan dan perkembangan dunia usaha. Ada beberapa ciri Sistem Ekonomi Kerakyatan, seperti: Bertumpu pada mekanisme pasar yang berkeadilan dengan prinsip persaingan yang sehat; 
Memperhatikan pertumbuhan ekonomi, nilai keadilan, kepentingan sosial, dan kualitas hidup; Mampu mewujudkan pembangunan berwawasan lingkungan dan berkelanjutan; Menjamin kesempatan yang sama dalam berusaha dan bekerja; Adanya perlindungan hak-hak konsumen dan perlakuan yang adil bagi seluruh rakyat Indonesia. Pengakuan lembaga internasional terhadap ekonomi kerakyatan menjadi modal besar bagi bangsa Indonesia yang sejak merdeka sudah menyusun konsep ekonomi kerakyatan dalam sistem perekonomian negaranya.

Konsep ekonomi kerakyatan merupakan konsep yang sejalan dengan apa yang sudah digariskan oleh Konstitusi RI, meskipun dalam pelaksanaannya masih belum dapat terlaksana dengan baik. Apabila konsep ini dapat dilaksanakan di Indonesia maka negara ini akan menjadi negara yang sangat maju, karena masyarakatnya sudah berdaya dalam bidang ekonomi. Konsep Tri Sakti yang dikemukakan oleh Presiden Pertama RI yakni Berdaulat dalam bidang politik, Berdikari dalam bidang ekonomi dan Berkepribadian dalam berbudaya akan terwujud. Berdikari dalam bidang ekonomi akan mampu terlaksana apabila sistem ekonomi kerakyatan mampu dilaksanakan secara murni dan konsekwen oleh pemerintah yang berkuasa. Ekonomi kerakyatan jangan hanya dijadikan komoditi kampanye saat pemilu, namun setelah terpilih janji mewujudkan ekonomi kerakyatan diabaikan karena harus memberikan prioritas kepada para konglemerat yang pada saat kampanye memberikan sumbangan dana yang besar bagi calon sehingga dapat terpilih sebagai penguasa. Ekonomi kerakyatan merupakan sistem yang akan mampu mencapai tujuan nasional Indonesia yakni mewujudkan masyarakat adil dan makmur. Ekonomi kerakyatan sesuai dengan amanat konstitusi RI apabila dilaksanakan sesuai dengan asanya maka Indonesia Sejahtera niscaya akan terwujud.

\section{E. Penutup}

Penanggulangan kemiskinan di Indonesia selama ini masih bersifat sektoral yang mengakibatkan program penanggulangan kemiskinan belum mampu menurunkan tingkat kemiskinan secara maksimal. Program yang dilaksankan oleh pemerintah daerah dan pemerintah pu- sat belum diselaraskan sehingga kadang terdapat program yang tumpang tindih dan tidak tepat sasaran. Penanggulangan masalah kemiskinan harus dilakukan dengan sistematik, sistemik dan periodik agar kompleksitas masalah kemiskinan dapat terurai dan lambat laun dapat diatasi secara maksimal.

Kemiskinan yang terjadi selama ini tidak terlepas dari keterlibatan masyarakat dalam sektor perekonomian. Masyarakat belum terlibat secara maksimal dalam sistem perekonomian, sehingga pertumbuhan ekonomi yang terjadi hanya dinikmati oleh sebagian kecil masyarakat. Sistem yang diterapkan oleh pemerintah juga belum mampu memberikan keberpihakan terhadap hasil perekonomian kepada masyarakat kebanyakan. Para konglemerasi masih menguasai sebagain besar aset-aset perekonomian di negeri ini. Sementara masyarakat yang mayoritas belum mampu bersaing dalam sistem yang cenderung mengarah ke sistem neo-libral yang terjadi saat ini.

Mendorong partisipasi masyarakat dalam sektor perekonomian harus terus dilakukan oleh semua pihak yang berkepentingan dalam penanggulangan kemiskinan. Pelibatan masyarakat secara maksimal dalam sektor perekonomian akan mampu meningkatkan pendapatan masyarakat yang berujung pada peningkatan kesejahteraan mereka. Perekonomian yang partisipatif memberikan peluang seluas-luasnya kepada seluruh rakyat untuk ikut berkontribusi dan menikmati hasil dari pertumbuhan ekonomi yang terjadi. Pelibatan masyarakat secara luas akan menekan tingkat kemiskinan yang ada, sehingga salah satu indikator kegagalan suatu pemerintahan dapat dieliminasi.

Ekonomi kerakyatan yang merupakan sistem perekonian yang sudah digariskan oleh konstitusi kita belum dapat dilaksanakan dengan baik. Intervensi pihak-pihak luar belum mampu membuat kita berdaulat di negeri sendiri khususnya dalam sektor ekonomi. Pelaksanaan ekonomi kerakyatan mutlak harus dilakukan dalam upaya penanggulangan kemiskinan di negeri ini. Peran UMKM, Koperasi dan lembaga-lembaga perekonomian milik masyarakat kebanyakan harus terus diberikan ruang maksimal dalam perekonomian nasional. Lembaga-lem- 
baga ekonomi kerakyatan sudah terbukti mampu bertahan dalam goncangan krisis ekonomi yang pernah terjadi melanda negara kita.

Strategi penanggulangan kemiskinan dengan memberikan kesempatan kepada masyarakat untuk ikut menikmati keberhasilan sektor ekonomi akan mampu meningkatkan kesejahteraan masyarakat secara luas. Perekonomian partisipatif yang berhasil diterapkan dalam suatu wilayah diyakini akan mampu mengangkat perekonomian kearah pertumbuhan ekonomi yang berkualitas. Pertumbuhan ekonomi berkualitas akan berdampak secara signifikan kepada peningkatan kesejahteraan masyarakat dan tentunya juga dapat menekan jumlah masyarakat miskin yang ada dalam wilayah tersebut.***

\section{Daftar Pustaka}

Hakim, Lukman. 2011. Pengantar Administrasi Pembangunan. Jogjakarta. Ar-Ruzz Media.

Kaho, J.R. 1997. Prospek otonomi di Negara Republik Indonesia. Jakarta. PT Raja Grafido persada.

Komite Penanggulangan Kemiskinan. 2005. Strategi Penanggulangan Kemiskinan (SNPK). Jakarta

Lembaga Penelitian SMERU. tt. Informasi Dasar Penanggulangan Kemiskinan.. Jakarta.
Leo Wiratma I Made, Djadijono M, Legowo TA.editors.2007. Membangun Indonesia Dari Daerah, Partisipasi Publik dan Politik Anggaran Daerah. Jakarta. CSIS.

Siagian. S. P. 1983, Administrasi Pembangunan : Konsep, Dimensi dan Strateginya, Jakarta, PT Gunung Agung

Sukirno, Sadono. 2007. Ekonomi Pembangunan, Jakarta,KencanaPrenada Media Group

Sumarto, Sudarno, Asep Suharyadi, Alex Arifianto. 2004. Tata Kelola Pemerintahan dan Penanggulangan Kemiskinan : Bukti-bukti Awal Desentralisasi di Indonesia. Lembaga Penelitian SMERU. Jakarta.

Suprayitno, Bambang. 2017. Ekonomi Publik; Konsep dan Implementasi Kebijakan. Yogyakarta.UPP STIM YKPK

Todaro, Michael P. Dan Stephen C Smith,. 2004. Pembangunan Ekonomi di Dunia Ketiga, edisi kedelapan. Jakarta. Penerbit Erlangga.

Undang-Undang Dasar Republik Indonesia dan Perubahannya, (Amandemen I, II, III dan IV), Penabur Ilmu.

https://bali.bps.go.id

https://tribun-bali.com 